\title{
Endo-1,4-3-xylanase B from Aspergillus cf. niger BCC14405 Isolated in Thailand: Purification, Characterization and Gene Isolation
}

\author{
Asano Krisana*, Sriprang Rutchadaporn, Gobsuk Jarupan, Eurwilaichitr Lily, \\ Tanapongpipat Sutipa and Kirtikara Kanyawim \\ National Center for Genetic Engineering and Biotechnology, \\ 113 Thailand Science Park, Paholyothin Rd., Klong 1, Klong Luang, Pathumthani 12120, Thailand
}

Received 23 March 2004, Accepted 26 April 2004

\begin{abstract}
During the screening of xylanolytic enzymes from locally isolated fungi, one strain $\mathrm{BCC} 14405$, exhibited high enzyme activity with thermostability. This fugal strain was identified as Aspergillus cf. niger based on its morphological characteristics and internal transcribed spacer (ITS) sequences. An enzyme with xylanolytic activity from BCC14405 was later purified and characterized. It was found to have a molecular mass of $\boldsymbol{c a}$. $21 \mathrm{kDa}$, an optimal pH of 5.0, and an optimal temperature of $55^{\circ} \mathrm{C}$. When tested using xylan from birchwood, it showed $K_{m}$ and $V_{\text {max }}$ values of $8.9 \mathrm{mg} / \mathrm{ml}$ and 11,100 U/mg, respectively. The enzyme was inhibited by $\mathrm{CuSO}_{4}$, EDTA, and by $\mathrm{FeSO}_{4}$. The homology of the 20-residue $\mathrm{N}$-terminal protein sequence showed that the enzyme was an endo-1,4$\beta$-xylanase. The full-length gene encoding endo-1,4- $\beta$ xylanase from BCC14405 was obtained by PCR amplification of its cDNA. The gene contained an open reading frame of $678 \mathrm{bp}$, encoding a 225 amino acid protein, which was identical to the endo-1,4-â-xylanase $B$ previously identified in $A$. niger.
\end{abstract}

Keywords: Aspergillus cf. niger, Endo-1,4- $\beta$-xylanase B, Hemicellulase, Thermostability, Xylanase

\section{Introduction}

Xylan (hemicellulose) is a polysaccharide composed of $\beta-1,4-$ linked xylopyranose units. It is highly branched and tightly associates with other biopolymers (Eriksson et al., 1990). Xylanolytic enzymes are a group of enzymes that hydrolyze

*To whom correspondence should be addressed. Tel: 66-2564-6700; Fax: 66-2564-6707

E-mail: krisanap@hotmail.com, krisana@biotec.or.th xylan and arabinoxylan polymers. This enzyme group includes endo-1,4- $\beta$-xylanase, (-xylosidase, (-arabinofuranosidase and acetylxylan esterase (Biely, 1993), and play important roles in the animal feed, pulp and paper, textile, and food industries. Other potential applications include the conversion of xylan in wastes from agriculture and food industries into xylose, and the production of fuel and chemical feedstocks (Sunna and Antranikian, 1997). Given their different modes of action and great variations in substrate/product specificities, xylanolytic enzymes are a major focus of applied research and of great interest for biotechnology applications. A number of xylanolytic enzymes from various sources, and especially from microorganisms, have been studied to understand their physical and biochemical characteristics (Sunna and Antranikian, 1997).

Due to their diversity, fungi have been recognized as a target for screening and as a source of new enzymes with useful and/or novel characteristics (Singh et al., 2003), and since high temperatures are used in many industrial processes, thermostability is one of the most desirable enzyme characteristics. Moreover, it has long been recognized that thermophiles represent a source of novel thermostable enzymes (Bruins et al., 2001).

The purpose of this study was to characterize the xylanolytic enzyme from a thermoresistant fungus (BCC14405). During the course of our studies we have tested 116 strains of thermoresistant fungi isolated from various sources in Thailand for xylanolytic activity and thermostability, and the strain BCC14405 exhibited the highest enzyme activity. In addition, its crude proteins retained high xylanolytic activity after heat treatment. Thus, strain BCC14405 was chosen for further investigation. The protein with this xylanase activity was initially purified and characterized to determine its biochemical and physical properties, and the full-length gene encoding this enzyme was cloned. Sequence analysis and homology modeling was performed to further classify the isolated enzyme. 


\section{Materials and Methods}

Microorganisms and plasmids Thermoresistant fungi were collected from several locations in Thailand. The strain BCC14405 was identified as a thermoresistant fungus with high xylanolytic activity, a voucher specimen has been deposited at the BIOTEC Culture Collection (BCC, Thailand). To induce enzyme production, the fungus was cultured in $5 \%$ wheat bran medium supplemented with $1.5 \%(\mathrm{w} / \mathrm{v})$ xylan as an inducer. Escherichia coli DH5aFí (Fír(lacZYA-argF)U169 deoR endAl hsdR17 supE44 thi-1 recAl gyr96 relA1 (f80dlacZ rM15) was grown at $37^{\circ} \mathrm{C}$ in $\mathrm{LB}$ broth (Sambrook and Russell, 2001) or on agar (1.5\% w/v) plates, and $E$. coli cells harboring a cloning vector, PGEM $^{\circledR}-\mathrm{T}$ Easy vector (Promega, Madison, USA), were cultured in LB medium supplemented with $100 \mu \mathrm{g} / \mathrm{ml}$ ampicillin.

Identification of the fungal strain The fungal strain BCC14405 was identified from its morphological characteristics and its internal transcribed spacer (ITS) sequences (Buchan et al., 2002). The genomic DNA (gDNA) of this fungus was isolated by using CTAB and phenol/chloroform method (Velegraki et al., 1999). The partial DNA fragment of ITS was amplified by polymerase chain reaction (PCR) using gDNA as a template. The ITS-F primer (5'-GCGGAA GGATCATTACTGAG-3') and ITS-R primer (5'-GGGTATCCCTA CCTGATCCG-3') were designed from the conserved ITS sequences of fungi (Yeates et al., 1998). The PCR product, $600 \mathrm{bp}$ in length, was cloned into pGEM $^{\circledR}-\mathrm{T}$ Easy vector (Promega, Madison, USA), and its sequences were obtained using the dideoxynucleotide chain termination method (Sambrook and Russell, 2001) and were analyzed. For biosafety testing, the cytoxicity of this fungal strain was tested using the standard cell lines, L929, BHK(21), HepG2, and IEC6 for cell viability determination using the MTT assay (Plumb et al., 1989).

Zymogram analysis The protein exhibiting xylanolytic activity was detected in crude extract by running it on native-PAGE. The gel was washed twice with distilled water and overlaid on AZCL-xylan agar $(0.1 \%(\mathrm{w} / \mathrm{v})$ xylan, $1.5 \%(\mathrm{w} / \mathrm{v})$ agar in $50 \mathrm{mM}$ sodium phosphate buffer, $\mathrm{pH}$ 5.8). The color zone of the azure dye released by the hydrolysis of AZCL-xylan was detected after incubation at $30^{\circ} \mathrm{C}$ for $2 \mathrm{~h}$. The protein band, corresponding to the position of the color zone, was then excised and subjected to the SDS-PAGE, and the SDS-PAGE gel was stained with Coomassie Brilliant Blue R250.

Purification of endo-1,4- $\beta$-xylanase $\quad$ BCC 14405 was cultured in $5 \%(\mathrm{w} / \mathrm{v})$ wheat bran broth in the presence of $1.5 \%$ xylan as an inducer for 6 days. The volume of the culture supernatant was adjusted with $2 \mathrm{M}$ Tris, $\mathrm{pH} 8.0$ to a final concentration of $60 \mathrm{mM}$ and applied to a DEAE Sepharose Fast Flow column (Amersham Biosciences, Buckinghamshire, UK), which had been equilibrated with $60 \mathrm{mM}$ Tris, $\mathrm{pH}$ 8.0. The flow-through solution, which contained the xylanolytic activity, was then adjusted to $1 \mathrm{M}$ $\left(\mathrm{NH}_{4}\right)_{2} \mathrm{SO}_{4}$ and $50 \mathrm{mM}$ sodium phosphate buffer, and $\mathrm{pH} 6.8$ (butter B). This solution was then applied to a Phenyl Sepharose 6 Fast Flow column (Amersham Biosciences, Buckinghamshire, UK) that had been equilibrated with buffer B. After the column had been washed with buffer $\mathrm{B}$, the protein concerned was eluted with
$500 \mathrm{mM}\left(\mathrm{NH}_{4}\right)_{2} \mathrm{SO}_{4}$ and $50 \mathrm{mM}$ sodium phosphate buffer, $\mathrm{pH} 6.8$ at a flow rate of $1 \mathrm{ml} / \mathrm{min}$.

Protein analysis Protein concentrations were determined using the Bradford method with bovine serum albumin as a standard (Bradford, 1976). Protein patterns were analyzed by SDS-PAGE (Laemmli, 1970), and the purity of the protein on SDS-PAGE was estimated by absorbance scanning using a Model GS-700 Imaging Densitometer equipped with Molecular Analyst Software (BioRad, Hercules, USA). The purified enzyme was blotted onto a PVDF membrane for $\mathrm{N}$-terminal protein sequencing.

Quantitative assay for xylanolytic activity Xylanolytic activity was quantitatively determined using 3,5-dinitrosalicyclic acid (DNS). The assay was based on the enzymatic hydrolysis of xylan, and the reaction of the liberated reducing sugar with DNS (Bailey et al., 1992). Xylose was used as a reference reducing sugar for preparing a standard curve. One unit of xylanase activity was defined as the quantity of enzyme that liberated reducing sugar at the rate of $1 \mu \mathrm{mole} / \mathrm{min}$. To establish optimal $\mathrm{pH}$ and temperature profiles, the enzyme-substrate reaction was carried out at different pHís and temperatures as described in the appropriate figure legends. In order to investigate thermostability and $\mathrm{pH}$ stability, the enzyme solution was incubated at different temperatures with different time intervals, or stored in buffers with different $\mathrm{pH}$ 's for 4 $\mathrm{h}$ before measuring activity under optimal conditions. To monitor the effects of different chemicals on enzyme activity, $\mathrm{CuSO}_{4}, \mathrm{CoCl}_{2}$, $\mathrm{ZnSO}_{4}, \mathrm{EDTA}, \mathrm{FeSO}_{4}, \mathrm{CuCl}_{2}, \mathrm{NaCl}, \mathrm{MgSO}_{4}, \mathrm{MgCl}_{2}, \mathrm{MnSO}_{4}$, sucrose, xylose, sorbitol, b-mercaptoethanol, acetic acid, or glycerol were added separately to the reaction solution, and enzymatic activities were measured under optimal conditions.

Substrate specificity The cellulase activity of the purified enzyme was assayed in a similar manner to its xylanase activity except that $1 \%(\mathrm{w} / \mathrm{v})$ carboxymethylcellulose and glucose were used as the substrate and reference sugar, respectively. The activities of $\beta$-xyloxidase, $\alpha$-L-arabinofuranosidase, and acetylxylan esterase were assayed for $10 \mathrm{~min}$ at $50^{\circ} \mathrm{C}$ using p-nitrophenyl- $\beta$-Dxylopyranoside, $\mathrm{p}$-nitrophenyl- $\alpha$-L-arabinofuranoside, and p-nitrophenyl acetate (Sigma, St. Louis, USA), respectively. Following the addition of 2 volumes of $1 \mathrm{M}$ sodium carbonate, the p-nitrophenol product was quantified at $405 \mathrm{~nm}$ using an absorbance coefficient of $18.5 \mathrm{ml} \cdot \mu \mathrm{mole}^{-1} \cdot \mathrm{cm}^{-1}$ (Lin et al., 1999). Azure Cross Link substrates (AZCL-substrate) (Megazyme, Ireland) were used to determine its enzymatic activity on the $\beta / \alpha$-glucosidic linkage. The method was based on the release of a colour labeling group, azure dye, after the hydrolysis of the AZCL-substrate. The AZCLsubstrate $(0.2 \%(\mathrm{w} / \mathrm{v}))$ was incubated with an equal volume of the enzyme solution with appropriate dilution at the optimal temperature for $30 \mathrm{~min}$. The reaction was stopped by heating at $95^{\circ} \mathrm{C}$ for $20 \mathrm{~min}$ and the mixture centrifuged. The absorbance of the supernatant was measured at $620 \mathrm{~nm}$. One unit of enzyme activity was defined as the amount of enzyme that produced 1 unit of absorbance of azure dye at $620 \mathrm{~nm}$ in one hour.

Cloning of the xylanase gene from $\boldsymbol{A}$. cf. niger BCC14405 Total RNA was isolated from BCC14405 which had been grown for 3 days in a wheat bran liquid medium containing xylan $(1.5 \% \mathrm{w} / \mathrm{v})$ at 
$30^{\circ} \mathrm{C}$ and Tri-reagent (MRC, USA), according to the manufacturer's instructions. First strand cDNAs, were synthesized from $1 \mathrm{mg}$ of total RNA using ImProm-II ${ }^{\mathrm{TM}}$ reverse transcriptase (Promega, Madison, USA). PCR was performed using a primer based on the nucleotide sequences of endoxylanases B from Aspergillus species (5'-ATGCTTACCAAGAACCTTCTC-3') and an oligo(dT) flanked primer (5'-CCGGAATTCAAGCTTCTAGAGGATCCT-3'). The PCR product was cloned into the cloning vector, pGEM $^{\circledR}-\mathrm{T}$ Easy (Promega, Madison, USA), and the resulting plasmid was then introduced into E. coli strain DH5a. Transformants were selected on LB plates supplemented with ampicillin $(100 \mathrm{mg} / \mathrm{ml})$, and the gene was identified by DNA sequencing.

\section{Results}

Identification of strain BCC14405 To identify the fungi that exhibited thermoresistant characteristics, collected specimens were heated at $80^{\circ} \mathrm{C}$ for $30 \mathrm{~min}$ and then isolated on potato dextrose agar (PDA). Strain BCC14405 collected from elephant dung, was able to grow on PDA after being incubated at $80^{\circ} \mathrm{C}$ for $30 \mathrm{~min}$. The xylan plate diffusion enzyme assay indicated that BCC14405 had high xylanolytic activity. From morphological observations, this strain had dark brown to black conidial heads, which is indicative of the Aspergillus section Nigri. To identify this strain at the molecular level, its internal transcribed spacer (ITS) sequence was amplified and analyzed. The alignment of this ITS fragment, $600 \mathrm{bp}$ in length (AY551186), showed that it was identical to those of $A$. niger UWFP515 (AY213633), A. phoenicis (U65307), A. tubingensis (AJ280008), and Gliocladium cibotii (AF048739). From these results, BCC14405 was identified as $A$. cf. niger. For the toxicity assay, a mouse fibroblast-like cell line (L929), a baby hamster kidney cell line (BHK(21)C13), a human hepatoma cell line (HepG2), and a rat small intestine cell line (IEC6) were exposed to crude extracts of $A$. cf. niger BCC14405 for $24 \mathrm{~h}$. Within the concentration range $6.25-200 \mu \mathrm{g} / \mathrm{ml}$, this fungal extract was not toxic to $\mathrm{BHK}(21) \mathrm{C} 13$, HepG2, or IEC6 cell lines. However, it was weakly toxic to $\mathrm{L} 929$ cells with an $\mathrm{ID}_{50}$ of $95 \pm 19 \mu \mathrm{g} / \mathrm{ml}$.

Zymogram When crude proteins in BCC14405 culture medium were subjected to native-PAGE, xylanolytic activity was detected using AZCL-xylan as substrate; only a single protein band showed enzyme activity (Fig. 1A). This protein was excised and subsequently subjected to SDS-PAGE, which showed that the molecular mass of the xylanolytic enzyme was approximately $21 \mathrm{kDa}$ (data not shown).

Purification and characterization of the xylanolytic enzyme from $\boldsymbol{A}$. cf. niger BCC14405 The enzyme was further purified using DEAE Sepharose and Phenyl Sepharose 6 Fast Flows. The purification steps are summarized in Table 1 , and resulted in a 5-fold purification with a yield of $20.7 \%$. The purified xylanolytic enzyme had specific activity of 5870
(A)
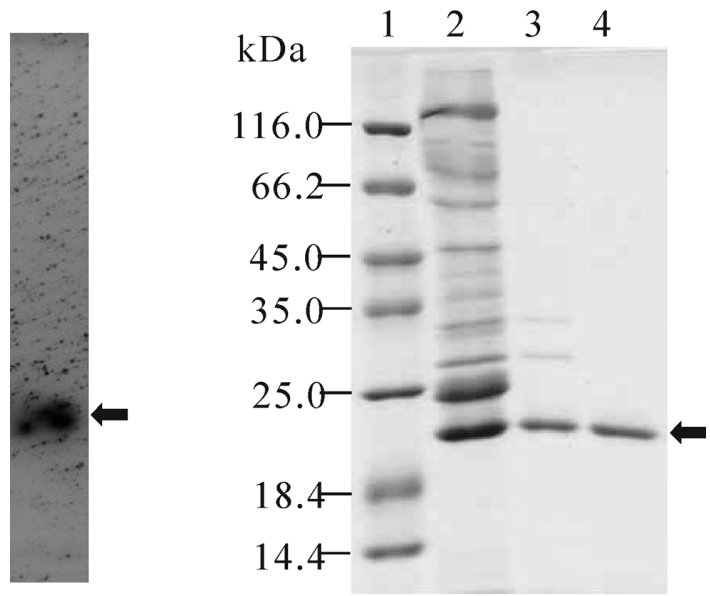

Fig. 1. (A) Zymogram showing the xylanolytic activity of $A$. cf. niger $\mathrm{BCC} 14405$ crude protein. Crude proteins were subjected to Native-PAGE and the gel was overlaid on AZCL-xylan agar. Xylanolytic activity, observed as azure dye release from AZCLxylan, was detected as a color zone. (B) SDS-PAGE analysis of protein components in the crude and purified fractions of endo1,4- $\beta$-xylanase from $A$. cf. niger BCC14405. Lane 1, Protein markers; lane 2, crude proteins; lane 3, partial purified fraction, flow-through fraction from a DEAE Sepharose Fast Flow column; lane 4, purified fraction, $500 \mathrm{mM} \mathrm{M}\left(\mathrm{NH}_{4}\right)_{2} \mathrm{SO}_{4}$ eluted fraction from a Phenyl Sepharose 6 Fast Flow column. The arrows indicate endo-1,4- $\beta$-xylanase from $A$. cf. niger BCC14405.

U/mg protein, and its molecular mass by SDS-PAGE mobility was approximately $21 \mathrm{kDa}$ (Fig. 1B), which agreed with the zymogram results. The purity of the purified protein, as estimated by SDS-PAGE and densitometry, was $81.1 \%$. Nterminal protein sequencing revealed an amino acid sequence of STPSSTGENNGFYYSFWTDG, and a homology search for this sequence using BLAST indicated a similarity to endoxylanases from Aspergillus species. The purified endo1,4- $\beta$-xylanase had maximal activity at $55^{\circ} \mathrm{C}$ and $\mathrm{pH} 5.0$ (Fig. $2 \mathrm{~A}$ and $2 \mathrm{~B}$ ). It retained $60 \%$ of its activity after being treated for $30 \mathrm{~min}$ at $50^{\circ} \mathrm{C}$ (Fig 3) and appeared to be stable at pHís greater than 5.0 (Fig. 2B). Interestingly, its thermostability was increased by $30-50 \%$ when $2 \mathrm{M}$ sorbitol was added to the enzyme solution (Fig. 3). At birchwood xylan concentrations ranging from 2.5 to $20 \mathrm{mg} / \mathrm{ml}$, the enzyme reaction was found to follow Michaelis-Menten kinetics with $K_{m}$ and $V_{\max }$ values of $8.9 \mathrm{mg} / \mathrm{ml}(\mathrm{n}=4)$, and 11,100 units $/ \mathrm{mg}$ protein respectively, as determined by a Lineweaver-Burk plot. The activity of the purified endo-1,4- $\beta$-xylanase was measured in the presence of various additives, refer to Fig. 4 for details. Most of the inorganic salts tested showed no significant effect on enzyme activity. However, $10 \mathrm{mM} \mathrm{CuSO}_{4}, \mathrm{EDTA}$, or $\mathrm{FeSO}_{4}$ lead to a $40-50 \%$ reduction in enzyme activity.

Substrate specificity Specific activity was measured using various substrates (Table 2). The results obtained showed that 
Table 1. Steps used to purify the xylanolytic enzyme in A. cf. niger BCC14405

\begin{tabular}{cccccccc}
\hline & $\begin{array}{c}\text { Protein } \\
\text { concentration } \\
(\mu \mathrm{g} / \mathrm{ml})\end{array}$ & $\begin{array}{c}\text { Total } \\
\text { volume } \\
(\mathrm{ml})\end{array}$ & $\begin{array}{c}\text { Total protein } \\
(\mu \mathrm{g} \text { protein })\end{array}$ & $\begin{array}{c}\text { Specific } \\
\text { activity } \\
(\mathrm{U} / \mathrm{mg} \text { protein })^{a}\end{array}$ & $\begin{array}{c}\text { Total activity } \\
(\mathrm{U})^{a}\end{array}$ & $\begin{array}{c}\text { Yield } \\
(\%)\end{array}$ & $\begin{array}{c}\text { Purification } \\
\text { fold }\end{array}$ \\
\hline Crude proteins & 21.6 & 60 & 1300 & 1180 & 1530 & 100.0 & 1.0 \\
DEAE-Sepharose & 4.05 & 89 & 360 & 3660 & 1320 & 86.3 & 3.1 \\
Phenyl-Sepharose & 2.25 & 24 & 54 & 5870 & 317 & 20.7 & 5.0 \\
\hline
\end{tabular}

${ }^{a}$ One unit of xylanase activity was defined as the quantity of enzyme required to liberate reducing sugar at rate of $1 \mu \mathrm{mole} / \mathrm{min}$.
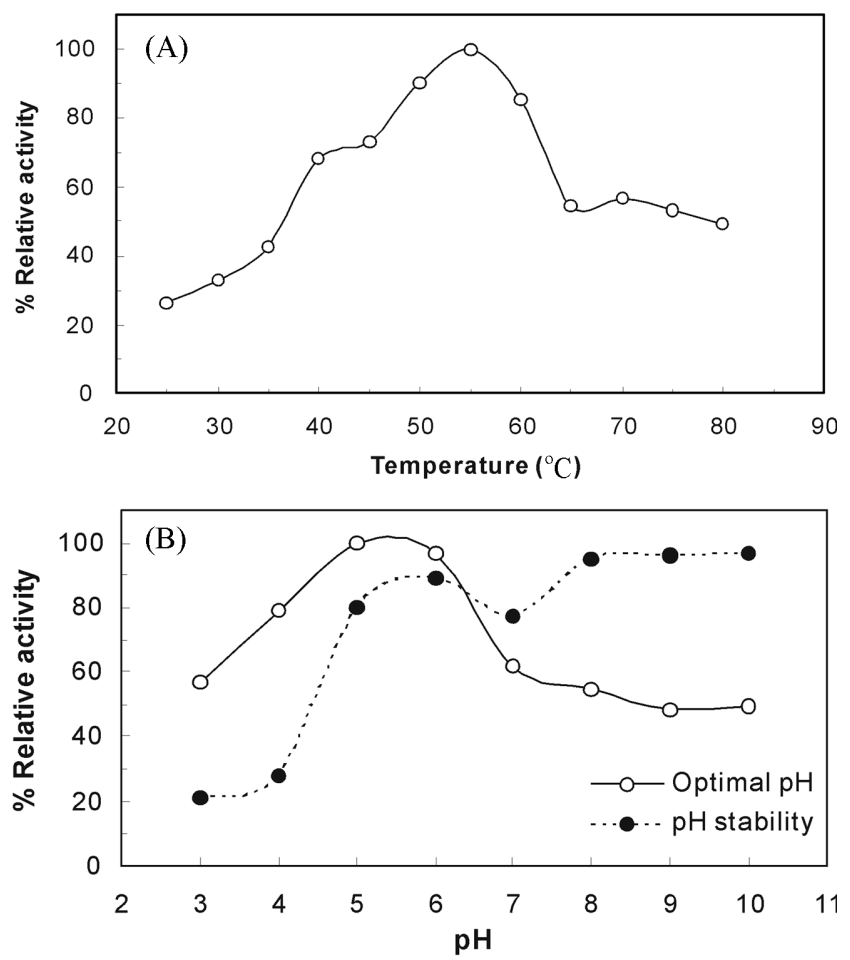

Fig. 2. Effects of temperature (A) and $\mathrm{pH}(\mathrm{B})$ on the activity of endo-1,4- $\beta$-xylanase from $A$. cf. niger BCC14405. The optimal temperature (A) was obtained by assaying the enzyme activity in $0.1 \mathrm{M}$ sodium phosphate buffer at different temperatures as indicates. The optimal $\mathrm{pH}$ (B, opened circle) was obtained by examining the effects of different $\mathrm{pH}$ values. The buffers used were $0.1 \mathrm{M}$ citrate buffer for $\mathrm{pH} 3.0-5.0,0.1 \mathrm{M}$ phosphate buffer for $\mathrm{pH}$ 6.0-7.0, and $0.1 \mathrm{M}$ Tris- $\mathrm{HCl}$ buffer for $\mathrm{pH} 8.0-10.0$. For $\mathrm{pH}$ stability testing ( $\mathrm{B}$, closed circle), the enzyme solutions were incubated at room temperature with different $\mathrm{pH}$ buffers for $4 \mathrm{~h}$ before standard activity assays were performed. The maximal activity as shown by each curve was defined as $100 \%$ relative activity.

the purified xylanase hydrolyzed only xylan and was free of cellulase, $\beta$-xylosidase, $\alpha$-L-arabinofuranosidase, acetylxylan esterase, amylase, and $\beta$-glucanase activity. Its ability to hydrolyze AZCL-xylan suggested that this enzyme is endoacting and that it cleaves the b-glucosidic bond linkage.

Cloning of the endo-1,4- $\boldsymbol{\beta}$-xylanase gene In order to

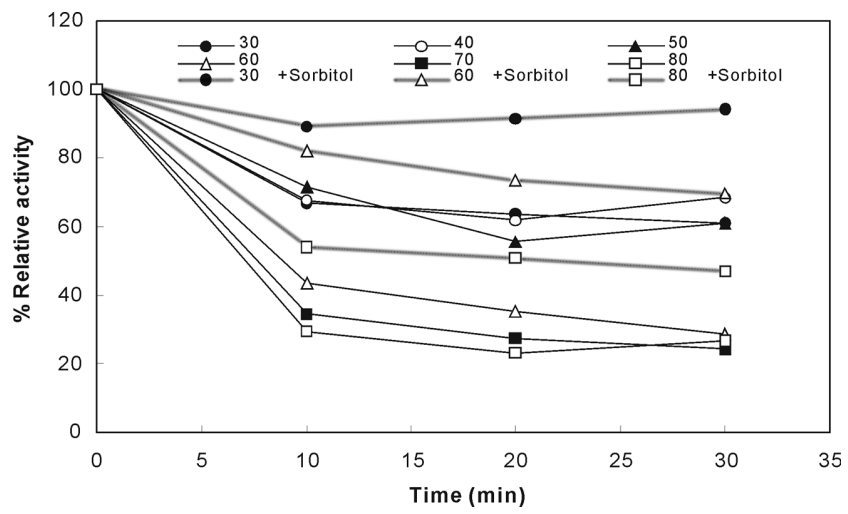

Fig. 3. Thermostability of endo-1,4- $\beta$-xylanase from $A$. cf. niger BCC14405. The enzyme solutions with (black lines) and without $2 \mathrm{M}$ sorbitol (dashed lines) were incubated at different temperatures for the indicated times intervals before performing standard activity assays.

identify and characterize the endo-1,4- $\beta$-xylanase gene, cDNAs were synthesized from total cellular RNA extract. The endo-1,4- $\beta$-xylanase gene was amplified using a primer designed on the basis of the nucleotide sequences of endoxylanases from Aspergillus species and an oligo (dT) flanked primer. Its 840-bp PCR product was cloned into pGEM $^{\circledR}-\mathrm{T}$ Easy vector, and the resulting recombinant plasmids were sequenced. The nucleotide sequence of this endo-1,4- $\beta$-xylanase gene, designated $x y l B$ (AY551187), revealed an open reading frame (ORF) of 678 bp and a GC content of $57.77 \%$. The ORF was predicted to code for a polypeptide of 225 amino acids with a molecular mass of $24 \mathrm{kDa}$ and $\mathrm{pI}$ of 1.71. This deduced amino acid sequence was found to be identical to that of endo-1,4-xylanase B from A. niger (AY126481-1). In addition, it showed 99, 94, and 74\% identities to the endo-1,4-xylanases from A. tubingensis (A39368-1), A. kawachii (D38070-1) and A. oryzae (AB044941-1), respectively. The N-terminal protein sequence of this purified enzyme, STPSSTGENNGFYYSFW TDG, corresponded to the amino acid residue numbers 38 to 57 (bold letters in Fig. 5), suggesting that the first 37-animo acids constituted a signal peptide. The molecular mass of the 178 amino acid mature protein was predicted to be $20.1 \mathrm{kDa}$, which corresponded with its SDS-PAGE determined size (Fig. 1B). 
Table 2. Substrate specificity of endo-1,4- $\beta$-xylanase from A. cf. niger BCC14405

\begin{tabular}{|c|c|c|}
\hline Substrate & Enzyme & Activity (U/mg) \\
\hline Xylan & Xylan hydrolytic enzymes & $5870^{a}$ \\
\hline Carboxymethyl cellulose & Carboxymethylcellulase & $\mathrm{ND}^{c}$ \\
\hline p-Nitrophenyl- $\beta$-D-xylopyranoside & $\beta$-Xylosidase & $\mathrm{ND}^{c}$ \\
\hline p-Nitrophenyl- $\alpha$-L-arabinofuranoside & $\alpha$-L-Arabinofuranosidase & $\mathrm{ND}^{c}$ \\
\hline p-Nitrophenyl acetate & Acetyl xylan esterase & $\mathrm{ND}^{c}$ \\
\hline AZCL-Xylan & Endo $1,4 \beta$-xylanase & $5260^{b}$ \\
\hline AZCL-HE cellulose & Cellulase & $\mathrm{ND}^{c}$ \\
\hline AZCL-Amylose & Amylase & $\mathrm{ND}^{c}$ \\
\hline AZCL- $\beta$-Glucan & Glucanase & $\mathrm{ND}^{c}$ \\
\hline
\end{tabular}

${ }^{a}$ One unit of enzyme activity was defined as the quantity of enzyme required to liberate reducing sugar at a rate of $1 \mu \mathrm{mole} / \mathrm{min}$. ${ }^{b}$ One unit of enzyme activity was defined as the amount of enzyme required to produce 1 unit of absorbance of azure dye at $620 \mathrm{~nm}$ in one hour.

${ }^{c} \mathrm{ND}$, activity could not be detected.

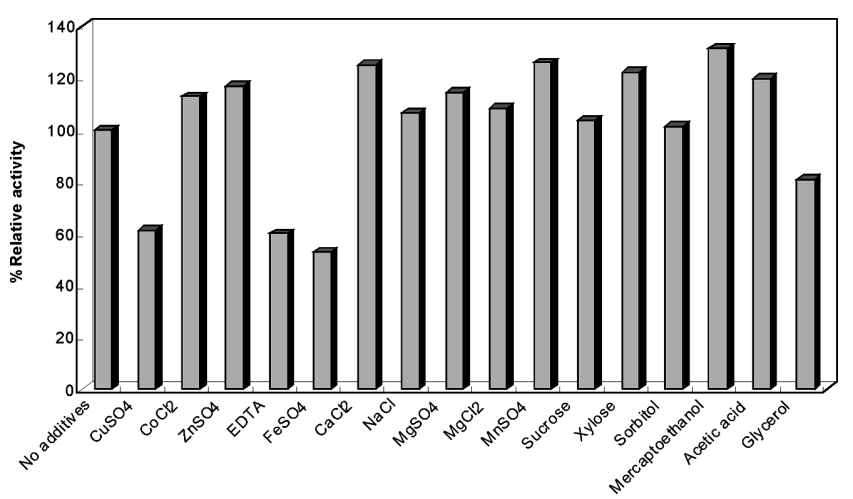

Fig. 4. Effects of additives on the activity of $A$. cf. niger BCC14405 endo-1,4- $\beta$-xylanase. The eEnzyme activities were assayed in the presence of $10 \mathrm{mM} \mathrm{CuSO}, 10 \mathrm{mM} \mathrm{CoCl}_{2}, 10$ $\mathrm{mM} \mathrm{ZnSO}$, $10 \mathrm{mM}$ EDTA, $10 \mathrm{mM} \mathrm{FeSO}, 10 \mathrm{mM} \mathrm{CuCl}_{2}, 10$ $\mathrm{mM} \mathrm{NaCl}, 10 \mathrm{mM} \mathrm{MgSO}$, $10 \mathrm{mM} \mathrm{MgCl} 2,10 \mathrm{mM} \mathrm{MnSO}_{4}, 10$ $\mathrm{mM}$ sucrose, $10 \mathrm{mM}$ xylose, $10 \%$ sorbitol, $0.1 \%$ mercaptoethanol, $0.1 \%$ acetic acid, and $10 \%$ glycerol. The enzyme activity in the absence of without any additives was defined as $100 \%$ relative activity.

\section{Discussion}

Fungi are among nature's most diverse organisms. It is estimated that there are approximately 1.5 million species of fungi (Hawksworth, 2001), approximately 12,000 of which have been found in Thailand (http://mycology.biotec.or.th/ Current_Research/Diversity/MainDiversity.htm). Due to the biodiversity shown by fungi, they have long been recognized as a source of valuable enzymes with novel characteristics. The strain BCC14405 was one of a number of local strains isolated from elephant dung, collected in Khao Yai National Park. It proved to be highly thermoresistant and showed continuous growth on PDA after heat treatment at $80^{\circ} \mathrm{C}$ for 30 min. Of the 116 thermoresistant fungal strains tested in a previous study, BCC14405 also exhibited the highest xylanolytic activity. Thus, this strain represents a potential industrial source of xylanolytic enzyme.

Based on its phenotypic characteristics and a phylogenetic analysis of its ITS data, BCC14405 was identified as A. cf. niger belonging to Aspergillus section Nigri. Many fungal strains belonging to this group are of economical important since they are widely used in the fermentation industry to produce organic acids and hydrolytic enzymes. However, some of its closely related species such as A. niger and $A$. carbonarius have been found to produce ochratoxins that often contaminate food and feed (Varga et al., 2003). Thus, we examined the cytotoxicity of $A$. cf. niger BCC 14405 but found no significant effect upon several standard cell lines. This finding indicates that $A$. cf. niger BCC14405 could be used for commercial enzyme production.

High levels of xylanolytic enzyme production were observed when A. cf. niger BCC14405 was cultivated in 5\% wheat bran broth supplemented with $1.5 \%$ xylan under aerobic conditions (data not shown). In the present study, a chromatography protocol was developed for purifying the enzyme. The optimal enzyme activity of the purified enzyme was observed at $55^{\circ} \mathrm{C}$ and $\mathrm{pH}$ 5.0. However, the activity of the purified enzyme was less stable than that of the crude protein extract. After incubating the enzyme for $30 \mathrm{~min}$ at $60^{\circ} \mathrm{C}$, its activity fell to $30 \%$, whereas the crude protein extract fell to only $90 \%$. These results suggest that some substances in the crude protein, such as chaperone proteins, may protect the enzyme from degradation at high temperatures. In addition, the purified enzyme was stable at $\mathrm{pH}$ values between 5.0 to 10.0 and was particularly thermostable after adding $2 \mathrm{M}$ sorbitol. Therefore, to prevent enzyme degradation during transportation and enzyme-handling, a $\mathrm{pH}$ of 8.0 and sorbitol (2M) supplementation is suggested. This positive effect of sorbitol on enzyme thermostability was first reported by Georgae et al. (2001), they found that when $2 \mathrm{M}$ sorbitol was added that Thermomonospora sp. xylanase residual activity increased by $30 \%$ after treatment $80^{\circ} \mathrm{C}$ for $30 \mathrm{~min}$ at $80^{\circ} \mathrm{C}$ of 


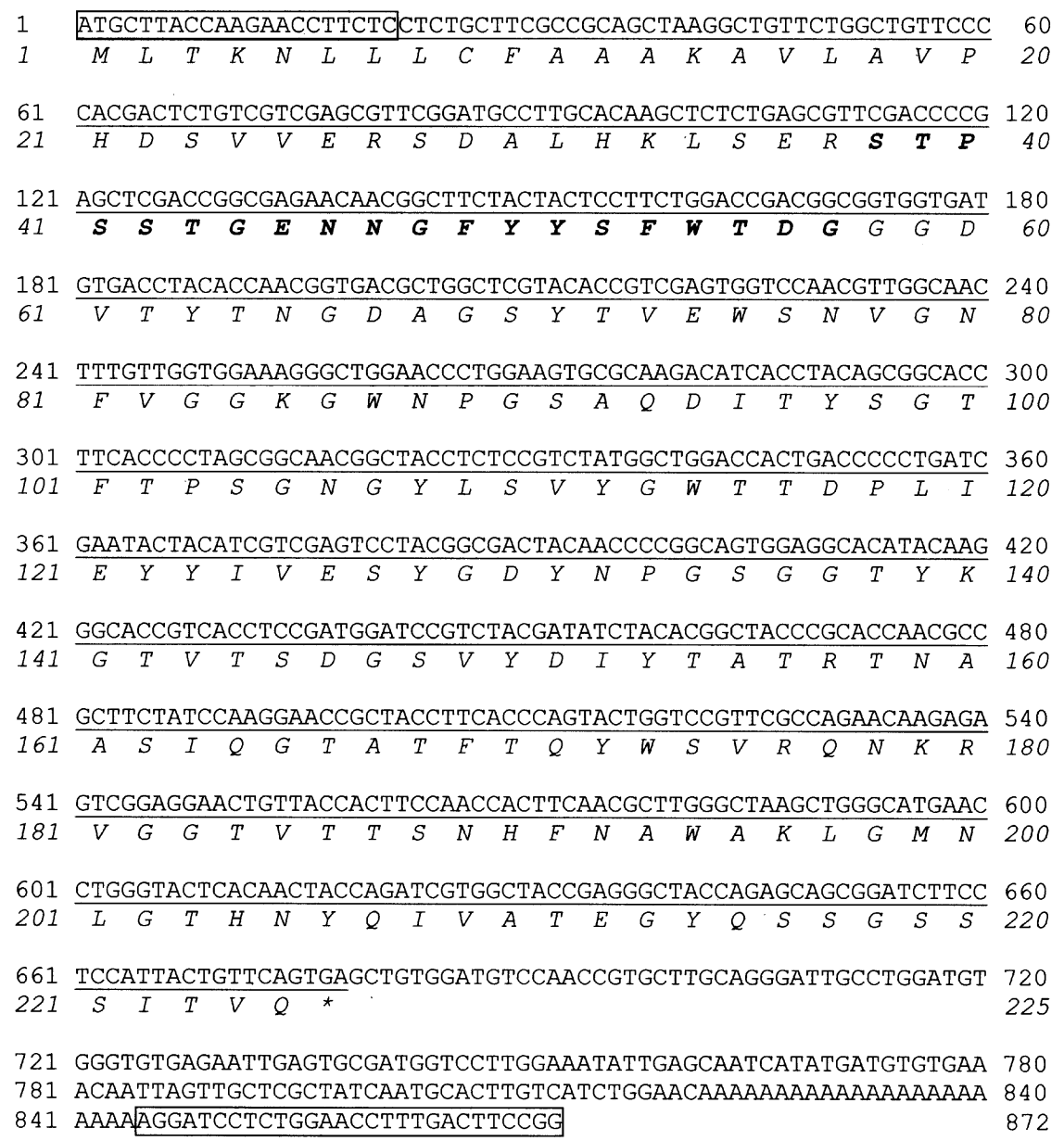

Fig. 5. Nucleotide sequence of the endo-1,4- $\beta$-xylanase gene ( $x y l B)$ from $A$. cf. niger BCC14405 and its flanking sequence (AY551187). The coding region of the gene is underlined. Deduced amino acids are shown as italic letters under the nucleotide sequence. Asterisk indicated the stop codon. The N-terminal protein sequence of the mature enzyme is given in bold. Primer sequences are boxed.

xylanase from Thermomonospora sp. was increased by $30 \%$. The sSorbitol, one of a polyols, was expected suggested to play a role in supporting the native conformation of the protein because of its due to its abilityy to maintain solvophobic interactions and its capability to form hydrogen bond. The $V_{\max }$ of the purified enzyme, 11,100 U/mg, indicated indicates that the enzyme was is capable of able to hydrolyzeing xylan faster than other those from other known organisms (Sunna and Antranikian, 1997). MoreoverIn addition, several chemicals and organic salts, and even its end product, the xylose, did not significantly influence the its enzyme enzymic activity (Fig. 4). Moreover, the lack of Noninhibitoryion effect of by $\beta$-mercaptoethanol and or acetic anhydride indicated that disulfide bonds and positively charged amino groups are not critical required for the enzyme its activity (Taneja et al., 2002).

The purified enzyme was a cellulase-free xylanase, which showed only endo-1,4- $\beta$-xylanase activity, and no activities of enzymes of the xylanolytic group, i.e., xylosidase, arabinofuranosidase, and acetate esterase activities. The Nterminal protein sequence of the mature enzyme suggests that the first 37-amino acid sequence is a signal peptide. In addition, the hydrophobic residues (54\%) of this peptide may allow penetration of the fungal membrane and subsequent release. These results corresponded to the homology analysis of its deduced amino acid sequence. Based on the relationships between the physiochemical properties of enzymes and their molecular weights and pIs, Wong et al. (1988) suggested that basic proteins with a low molecular weight belong to family 10 and that acidic proteins of high molecular weight belong to family 11 . However, the endo- $\beta$ 1,4-xylanase from $A$. cf. niger BCC14405, which has a low molecular weight and a low pI is an exception to this general pattern. Since the tertiary structure predicted for this protein, based on Burkhard Rostís sequence analysis and structure prediction server, showed that it belongs to family 11 .

At least 5 xylanases have been found in A. niger, (John et al., 1979; Berrin et al., 2000). These differ in molecular mass (from 20 to $50 \mathrm{kDa}$ ) and amino acid sequence. Most of the detailed information on enzyme properties, function, and structure available was derived from study of endoxylanase type A (Gorbacheva and Rodionova, 1977; Berrin et al., 2000; 
Tahir et al., 2002). Based on structural analysis, both endoxylanase A and B belong to family 11 . However, they are classified as type A and B because their amino acid sequences share only $41 \%$ identity. Although, the amino acid sequences of endo-1,4-endoxylanases B from A. niger (AY126481-1), A. tubingensis (A39368-1), and A. kawachii (D38070-1) were available on the database, their properties have not been reported. In addition, de Graaff et al. (1994) showed that $A$. tubingensis NW756A produces endoxylanase $\mathrm{B}$ in low quantity and found that the enzyme is difficult to purify from culture broth (Patent number US 5,610,046).

The Thai isolate $A$. cf. niger BCC14405 produced endoxylanase $\mathrm{B}$ as the main xylanolytic enzyme (Fig. 1A). Here we report the purification, characterization, and the nucleotide sequence of the endoxylanase B from the wild-type fungus, $A$. cf. niger, for the first time. Because it has a high $V_{\max }$ and chemical tolerance, this endo- $\beta-1,4$-xylanase could be useful for several industrial applications, such as, xylan conversion in wastes from agricultural and food industries. In order to improve the production of this enzyme and its stability under extreme conditions, the $x y l B$ gene will be mutagenized and overexpressed in E. coli.

Acknowledgments We thank Dr. Janet Jennifer Luangsaard for providing the thermoresistant fungal strains and Asst. Prof. Dr. Kusol Pootanakit for his critical reading of the manuscript. This work was supported by a grant (B21FH0012) from the National Center for Genetic Engineering and Biotechnology, National Science and Technology Development Agency, Thailand.

\section{References}

Bailey, M. J., Biely, P. and Poutanen, K. (1992) Interlaboratory testing of methods for assay of xylanase activity. J. Biotechnol. 23, 257-270.

Berrin, J. G., Williamson, G., Puigserver, A., Chaix, J. C., McLauchlan, W. R. and Juge, N. (2000) High-level production of recombinant fungal endo-beta-1,4-xylanase in the methylotrophic yeast Pichia pastoris. Protein Expr. Purif. 19, 179-187.

Biely, P. (1993) Biochemical aspects of the microbial hemicellulases; in Hemicelluloses and Hemicellulase, Coughlan, M. and Hazlewood, G. (eds.), pp. 29-51, Portland Press, London, UK.

Bradford, M. M. (1976) A rapid and sensitive method for the quantitation of microgram quantities of protein utilizing the principle of protein-dye binding. Anal. Biochem. 72, 248-254.

Bruins, M. E., Jasen, A. E. and Boom R. M. (2001) Thermozymes and their applications: a review of recent literature and patents. Appl. Biochem. Biotechnol. 90, 155-186.

Buchan, A., Newell, S. Y., Moreta, J. I. and Moran, M. A. (2002) Analysis of internal transcribed spacer (ITS) regions of rRNA genes in fungal communities in a southeastern U.S. salt marsh. Microb. Ecol. 43, 329-340.

Eriksson, K. E. L., Blanchette, R. A. and Ander, P. (1990) Biodegradation of hemicelluloses; in Microbial and Enzymatic
Degradation of Wood and Wood Components, Eriksson, K. E. (ed.), pp. 181-187, Springer-Verlag, Berlin, Germany.

George, S. P., Ahmad, A. and Rao, M. B. (2001) A novel thermostable xylanase from Thermomonospora sp.: influence of additives on thermostability. Bioresour. Technol. 78, 221-224.

Gorbacheva, I. V. and Rodionova, N. A. (1977) Studies on xylan degrading enzymes. I. Purification and characterization of endo1,4-beta-xylanase from Aspergillus niger str. 14. Biochim. Biophys. Acta 484, 79-93.

Hawksworth, D. L. (2001) The Magnitude of fungal diversity: the 1.5 million species estimated revisited. Mycol. Res. 105, 14221432.

John, M., Schmidt, B. and Schmidt, J. (1979) Purification and some properties of five endo-1,4-beta-D-xylanases and a betaD-xylosidase produced by a strain of Aspergillus niger. Can. J. Biochem. 57,125-134.

Laemmli, U. K. (1970) Cleavage of structural proteins during the assembly of the head of bacteriophage T4. Nature 227, 680685.

Lin, J., Ndlovu, L. M., Singh, S. and Pillay, B. (1999) Purification and biochemical characteristics of beta-D-xylanase from a thermophilic fungus, Thermomyces lanuginosus-SSBP. Biotechnol. Appl. Biochem. 30, 73-79.

Plumb, J. A., Milroy, R. and Kaye, S. B. (1989) Effects of the pH dependence of 3-(4,5-dimethylthiazol-2-yl)-2,5-diphenyltetazolium bromide-formazan absorption on chemosensitivity determined by a novel tetrazolium-based assay. Cancer Res. 49, 44354440.

Sambrook, J. and Russell, D. W. (2001) Molecular Cloning: A Laboratory Manual, 3rd ed., Cold Spring Harbor Laboratory Press, New York, USA.

Singh, S., Madlala, A. M. and Prior, B. A. (2003) Thermomyces lanuginosus: properties of strains and their hemicellulases. FEMS Microbiol. Rev. 27, 3-16.

Sunna, A. and Antranikian, G. (1997) Xylanolytic enzymes from fungi and bacteria. Crit. Rev. Biotechnol. 17, 39-67.

Tahir, T. A., Berrin, J. G., Flatman, R., Roussel, A., Roepstorff, P., Williamson, G. and Juge, N. (2002) Specific characterization of substrate and inhibitor binding sites of a glycosyl hydrolase family 11 xylanase from Aspergillus niger. J. Biol. Chem. 277, 44035-44043.

Taneja, K., Gupta, S. and Kuhad, R. C. (2002) Properties and application of a partially purified alkaline xylanase from an alkalophilic fungus Aspergillus nidulans KK-99. Bioresour. Technol. 85, 39-42.

Varga, J., Rigó, K., Tóth, B., Téren, J. and Kozakiewicz, Z. (2003) Evolutionary relationships among Aspergillus species producing economically important mycotoxins. Food Technol. Biotechnol. 41, 29-36.

Velegraki, A., Kambouris, M., Kostourou, A., Chalevelakis, G. and Legakis, N. J. (1999) Rapid extraction of fungal DNA from clinical samples for PCR amplification. Food Technol. Biotechnol. 37, 69-73.

Wong, K. K. Y., Tan, L. U. L. and Saddler, J. N. (1988) Multiplicity of $\beta-1,4$-xylanase in microorganisms: function and applicants. Microbiol. Rev. 52, 305-317.

Yeates, C., Gillings, M. R., Davison, A. D., Altavilla, N. and Veal, D. A. (1998) Methods for microbial DNA extraction from soil for PCR amplification. Biol. Proced. Online 1, 40-47. 